INTERNATIONAL JOURNAL OF ENVIRONMENT

Volume-3, Issue-4, Sep-Nov 2014

ISSN 2091-2854

Received:10 July

Revised:21 August

Accepted:19 November

\title{
PCBS CONTAMINANTION OF TRANSFORMER OIL AND ITS OCCUPATIONAL HEALTH AND SAFETY STATUS IN THE KATHMANDU VALLEY, NEPAL
}

\author{
Laxman K.C. ${ }^{*}$ and Bhupendra Devkota \\ College of Applied Sciences - Nepal, Tribhuvan University, Nepal \\ *Corresponding author: luxkunwar@gmail.com
}

\begin{abstract}
Electrification in Kathmandu valley had started in 1911 and the use of polychlorinated biphenyls (PCBs) probably started since 1940s (Devkota, 2005). This research work was undertaken to find out the degree and extent of PCBs contamination in transformer oil and to explore its impacts on occupational health and safety issues of the workers and on the environment. The research was focused on Distributions Centers of the Nepal Electricity Authority (NEA) in the Kathmandu valley, NEA Lainchaur workshop and welding workshops of the Kathmandu valley. The samples of transformer oil were collected, safely stored and analyzed using L2000DX Chloride Analyzer, PCBs contamination at $>50 \mathrm{ppm}$ level was found in 184 distribution transformers with total volume of PCBs contaminated transformer oil to be $67566.3 \mathrm{Kg}$. The knowledge on impacts of PCBs contaminated transformer oil on human health and environment was better among NEA employees than among employees of welding workshops, though not satisfactory. Due to very low awareness, the workers come in contact with the transformer oil regularly and many health impacts such as eye problems, skin related complication, weakness and respiratory problems might be due to this exposure; however, exact impacts could not be verified scientifically.

Key Words: Distribution Centres, Persistent Organic Pollutant (POPs), Polychlorinated Biphenyls (PCBs), Sub Stations, Transformers
\end{abstract}




\section{Introduction}

PCBs oils were initially proposed as transformer oil for use in electrical equipment like transformers because of their excellent dielectric properties and also because of their very low flammability. During incomplete combustion of PCBs mixed transformer oil, very toxic chemicals dibenzofurans are formed, and they have deleterious effects on health. Apart from the danger of PCBs producing furans in the case of fires, PCBs themselves are hazardous substances because of their high toxicity, great stability, and are easily absorbed by the fatty tissues of humans and animals. PCBs concentrations can then build up in the body, for example in the fat, the liver, etc., and these molecules are very difficult to eliminate (Safe et al., 1985). Due to having such impacts, PCBs were gradually phased out for applications in transformers from the early 1980s, depending on the country. PCB was produced till 1990, and thus equipment manufactured before 1990 may contain PCBs. However, very large number of transformers may still contain and may have been the source of cross-contamination of PCBs even today. The main risks from these transformers are leaking of PCBs oils into the environment, accumulation in different environmental components and increased difficulty in the management after the end of the working life of the transformers.

The most important and unaddressed issue so far is the human health and environmental impacts of PCBs contaminated transformer oil, used either in the transformers or in the welding machines as welding machines also use old transformers oil in Nepal (Devkota, 2005). The health impacts of workers like NEA employees and employees at the metal welding workshops exposed to such contaminated oil need special attention. Therefore a need was felt to explore the knowledge about PCBs contamination in transformer oil and its impacts on human health and environment among occupationally linked workers in the Kathmandu valley and identifying areas where awareness about the issue needs to be improved.

The Stockholm Convention is a global treaty to protect human health and the environment from persistent organic pollutants (POPs) including PCBs. Nepal being the party, government should take measures to eliminate or reduce the release of POPs into the environment. Therefore this research was undertaken to quantify the volume of PCBs contaminated transformers oil in the Kathmandu Valley. 


\section{Materials and Methods}

This research was carried out within the Kathmandu valley covering 53 power transformers and 2988 distribution transformers within 8 sub stations and 10 distribution centres, NEA Lainchaur workshop and welding workshops.

Both quantitative and qualitative methods were used for the study. Quantitative method was used to analyze the degree and extent of PCBs contamination in transformer oil through L2000DX PCBs/Chloride Analyzer System [UNEP recommended test kits], all possible NEA transformer oil of Kathmandu valley was tested for PCBs concentration. For the analysis of transformer oil sample in L2000DX, first PCBs/ chlorinated organic in the sample were chemically converted to chlorine. Upon the completion of the conversion procedure, all the chlorinated organic content of the transformer oil sample were converted to chlorinated ions and this chloride content in the final extract was then quantified using a chloride specified electrode and converted to an equivalent analyte concentration using the conversion factors programmed into the analysis of the instrument. Qualitative method was done through field visits and questionnaire survey. Field visit was done to collect general information of transformers like transformer status, leakage condition and cause of the leakage, possible soil and water contamination from the leak, location and condition of the transformers and general and technical information of transformers like manufacture date and manufacturing country and was done for all possible transformers. A questionnaire survey among randomly selected 38 NEA employees and 90 employees of Welding Workshops, who were occupationally linked to transformer oil, was done by using purposive and convenience sampling strategies, mainly through semi structured questionnaires to obtain qualitative data on workers perception about health and environmental impacts of PCBs contaminated transformers oil. This was chosen as the most appropriate and feasible tool because it gives more in depth perspective from each participant and allows a more flexible and exploratory approach than simple questionnaires.

\section{Result and Discussions}

\section{PCBs Contamination}

In Nepal there are 256 power transformers located at different Generating Stations, Grid Substations, Distribution Centers under NEA (MOEST, 2006). The study made on 53 power transformers located at different grids and substations within the Kathmandu valley showed no 
PCBs contamination; such transformers, therefore can simply be managed by using ordinary safety precautions. More than 25 percent of power transformers were found to be more than 30 years of age and these transformers may show higher possibility of failure at any course of time (Basel Convention, 2003).

Out of 50 old and decommissioned distribution transformers stored at Lainchaur Workshop in 2006 (MOEST, 2007), only 17 were found during the present study. Among 17 decommissioned transformers, PCBs contamination at greater than or equal to $50 \mathrm{ppm}$ level was found in 7 transformers, as there was very little oil in these transformers, we could expect to manage them easily, however container contamination should be taken into consideration and must detect the PCBs contamination on the container and should safely dispose, if found contaminated (Stockholm Convention, 2004).

Among 30 transformers under maintenance 5 transformers were found contaminated with PCBs at greater than or equal to $50 \mathrm{ppm}$ level, therefore during their maintenance PPE and other possible safety measures must be used and PCBs free transformer oil should be filled after maintenance (Safe and Hutzinger, 1984).

Among 2112 online distribution transformers PCBs contamination (PCBs level equal or greater than $50 \mathrm{ppm}$ ) was found in 172 transformers. As the Basel and Stockholm Conventions recommend phase-out of PCBs contaminated transformers (under specific timelines) rather than continued use so if possible replacement of the contaminated transformers with new PCB free transformers should be done and if not possible refilling the same transformers with a non PCBs fluid like silicones, aliphatic hydrocarbons, poly-a-olefins, chlorinated benzenes and esters should be done (UNEP, 1997).

Table 1: Number of PCBs contaminated transformers and volume of oil in different distribution centers of the Kathmandu valley

\begin{tabular}{|l|l|l|l|l|l|}
\hline S.N. & Distribution Centre & \multicolumn{2}{|l|}{ Number of Transformers } & PCBs \\
\cline { 3 - 5 } & & Total & $\begin{array}{l}\text { Oil Sample } \\
\text { Collected } \\
\text { contaminated } \\
\text { Transformer oil } \\
\text { (in Kgs })\end{array}$ & $\begin{array}{l}\text { PCBs } \\
\text { contaminated } \\
(>/=50 \mathrm{ppm})\end{array}$ \\
\hline 1. & Kathmandu Centre & 639 & 395 & 69 & 13439 \\
\hline 2. & Kathmandu East & 345 & 316 & 16 & 3455.5 \\
\hline 3. & $\begin{array}{l}\text { Kathmandu North } \\
\text { East }\end{array}$ & 90 & 65 & 5 & 627.8 \\
\hline
\end{tabular}




\begin{tabular}{|l|l|l|l|l|l|}
\hline 4. & Kathmandu-North & 232 & 207 & 4 & 479.6 \\
\hline 5. & Kathmandu-West & 497 & 373 & 50 & 10034.4 \\
\hline 6. & Lalitpur & 489 & 303 & 14 & 2261.8 \\
\hline 7. & Pulchowk & 175 & 168 & 2 & 450 \\
\hline 8. & Bhaktapur & 234 & 72 & 8 & 1273.4 \\
\hline 9. & Thimi & 112 & 114 & 3 & 639.4 \\
\hline 10. & Kirtipur & 175 & 99 & 1 & 155 \\
\hline Total & 2988 & 2112 & 172 & 32815.9 \\
\hline
\end{tabular}

The main problem associated with these PCBs contaminated transformers is to prevent releases of PCBs contaminated oil are; transfer of liquid PCBs during retrofilling, replacement of leaking seals and repair of cracks and holes, clean-up of minor leaks or spills and timely addition of non contaminated transformer oil (UNEP Chemicals, 1999). The presence of PCBs in all the transformer oil might be possibly due to cross-contamination, either during addition of oil to online transformers or during maintenance as Nepal Electricity Authority (NEA) has coded that the transformer should be PCBs free for purchase and import (NEA, 2011). At the same time there is also possibility that the new transformer might also contain PCBs contaminated oil as till now there is no provision and facility to examine and monitor the PCBs content in new transformers.

Table 2: Volume of PCBs contaminated transformer oil

\begin{tabular}{|l|l|l|l|l|}
\hline S.N. & Transformer Categories & \multicolumn{2}{|l|}{ Number of Transformers } & $\begin{array}{l}\text { PCBs } \\
\text { contaminated } \\
\text { transformer oil } \\
\text { (in Kgs) (PCBs } \\
>/=50 \mathrm{ppm})\end{array}$ \\
\cline { 3 - 5 } & & Total & $\begin{array}{l}\text { PCBs } \\
\text { contaminated(PCBs } \\
>/=50 \mathrm{ppm})\end{array}$ & 0 \\
\hline 1. & Power Transformers & 53 & 0 & 7 \\
\hline 2. & Phase out transformers & 17 & 7 & 343.4 \\
\hline 3. & $\begin{array}{l}\text { Transformers under } \\
\text { maintenance }\end{array}$ & 30 & 5 & 32815.9 \\
\hline 4. & Online distribution transformers & 2988 & 172 & 33166.3 \\
\hline Total & & 3088 & 184 & \\
\hline
\end{tabular}


Almost $50 \%(34400 \mathrm{Kg})$ of the PCBs contaminated transformer oil is stored at Lainchaur workshop of NEA. Every time during the maintenance of transformers, all the oil of the transformer is pumped out and stored at same PCBs contaminated tank, and after maintenance the oil from the tank is pumped back to the transformers simply after filtration. During this process on one hand all the uncontaminated transformer oil gets contaminated and on the other hand highly concentrated PCBs in transformer oil gets diluted. Therefore immediate action needs to be taken on management and disposal of contaminated transformers oil and purchase and use of uncontaminated oil in this workshop. At the same time each transformer brought for maintenance should be first tested for PCBs concentration in its oil, through test kits and if contaminated should be separated, safely disposed and uncontaminated or new oil must be filled after maintenance. During each purchase of transformer oil, the PCBs concentration must be examined and monitored for any illegal import. By this process, all the PCBs contaminated oil can be collected and safely disposed.

\section{Occupational Health and Safety Conditions}

It is most difficult to establish cause and effect relationships for human exposure of PCBs and associated toxic gases and incident disease, as humans encounter a broad range of environmental exposures and frequently to a mixture of chemicals at any one time. This difficulty is further underscored by the fact that POPs rarely occur as single compounds (UNEP Chemicals, 1999). More to the point, however, is the fact that PCBs are likely to accumulate, persist and bioconcentrate and could, thus, achieve toxicologically relevant concentrations even though distinct exposure may appear limited (UNEP Chemicals, 1999). Experimentally, the weight of scientific evidence (WHO, 2001) suggests that PCBs and associated toxic gases have potential to cause significant adverse effects to human health, at the local level, and at the regional and global levels through long-range transport. Therefore, occupational and accidental high-level exposures are of concern for both acute and chronic worker exposures.

All the respondents, due to the nature of jobs were male; so, male were more vulnerable to PCBs exposure and associated toxic gases. However few females and their children were also found around the working area. Almost all the respondents said that they did not change their working dress at their homes, so it is quite possible that female and children are also vulnerable to be exposed to PCBs and associated toxic gases. Maximum number of respondents were of 
reproductive age group, indicating that their developing fetus and neonate were also vulnerable to PCBs exposure due to transplacental and lactational transfer of maternal burdens at critical periods of development (WHO, 2001). As few children's were also found working with PCBs contaminated transformer oil, they may experience rates of infection some 10-15 times higher than comparable children without PCBs exposure (Safe and Hutzinger, 1984).

On the basis of years of the services of the respondents, high possibility of chronic exposure was observed among NEA workers because of stable job and long duration of service, whereas comparatively higher possibility of acute exposure to PCBs and associated toxic gases was observed among welding workshop workers because of higher temperature of welding machine and very close contact with such equipment.

The level of knowledge about impact of PCBs contaminated transformer oil and associated toxic gases on the health were very poor among respondents. However in last 7 years the level of awareness has remarkably improved [10.8\% of the NEA workshop employees and $4 \%$ of the private workshops employees were aware of health effects of PCBs in 2006 (MOEST, 2007)]. The level of awareness was higher among the NEA employees than welding workshop workers but when all respondents considered majority of the workers did not know about the impacts of transformer oil on health. As the workers regularly come in contact with PCBs contaminated transformer oil either during their work or due to wrong perception of use such transformer oil as a remedy for massage, wound healing, pain relief, blood clotting etc., many health problems like eye problems, skin related complications, decreased immunity power, respiratory problems, etc. might have occurred. 


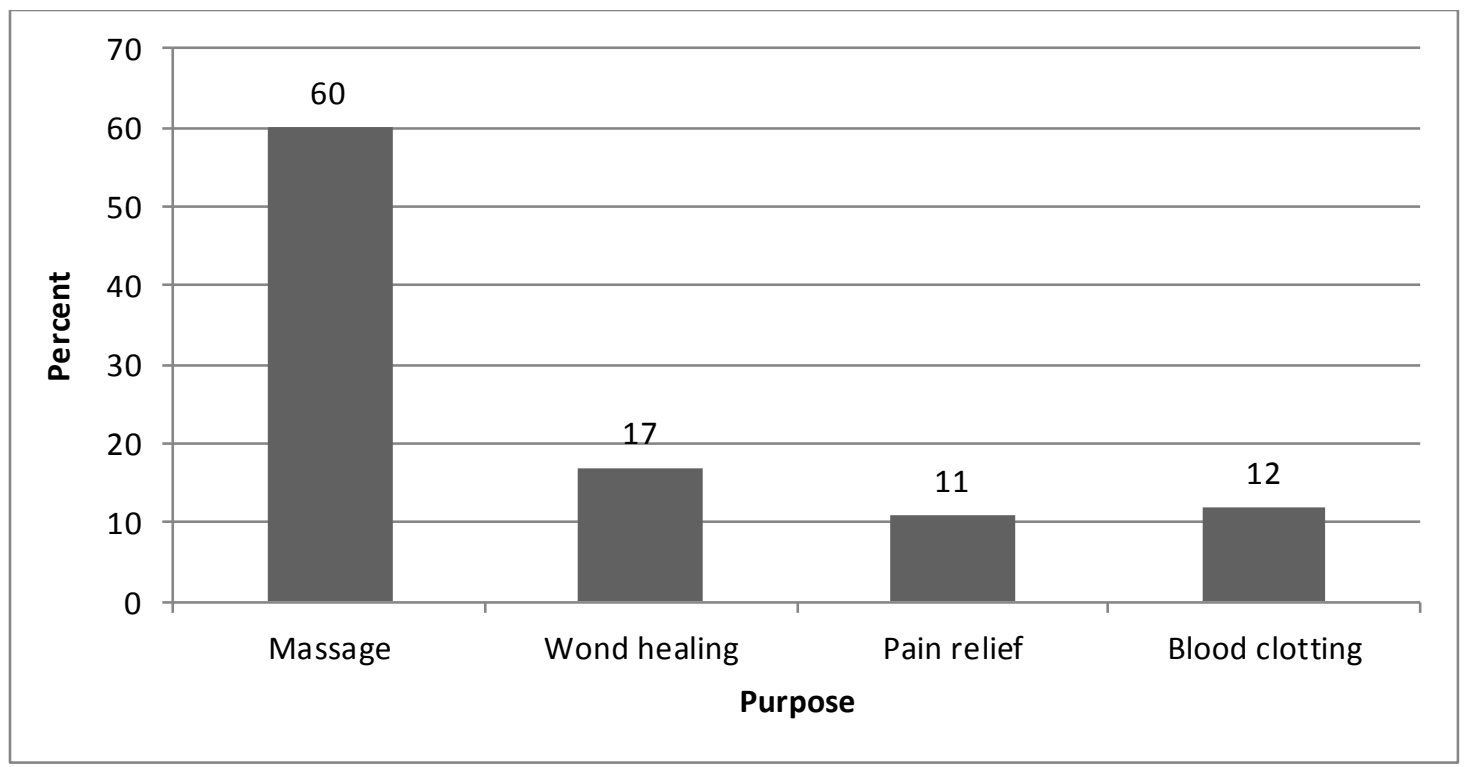

Figure 1: Different medical application of transformer oil among respondents

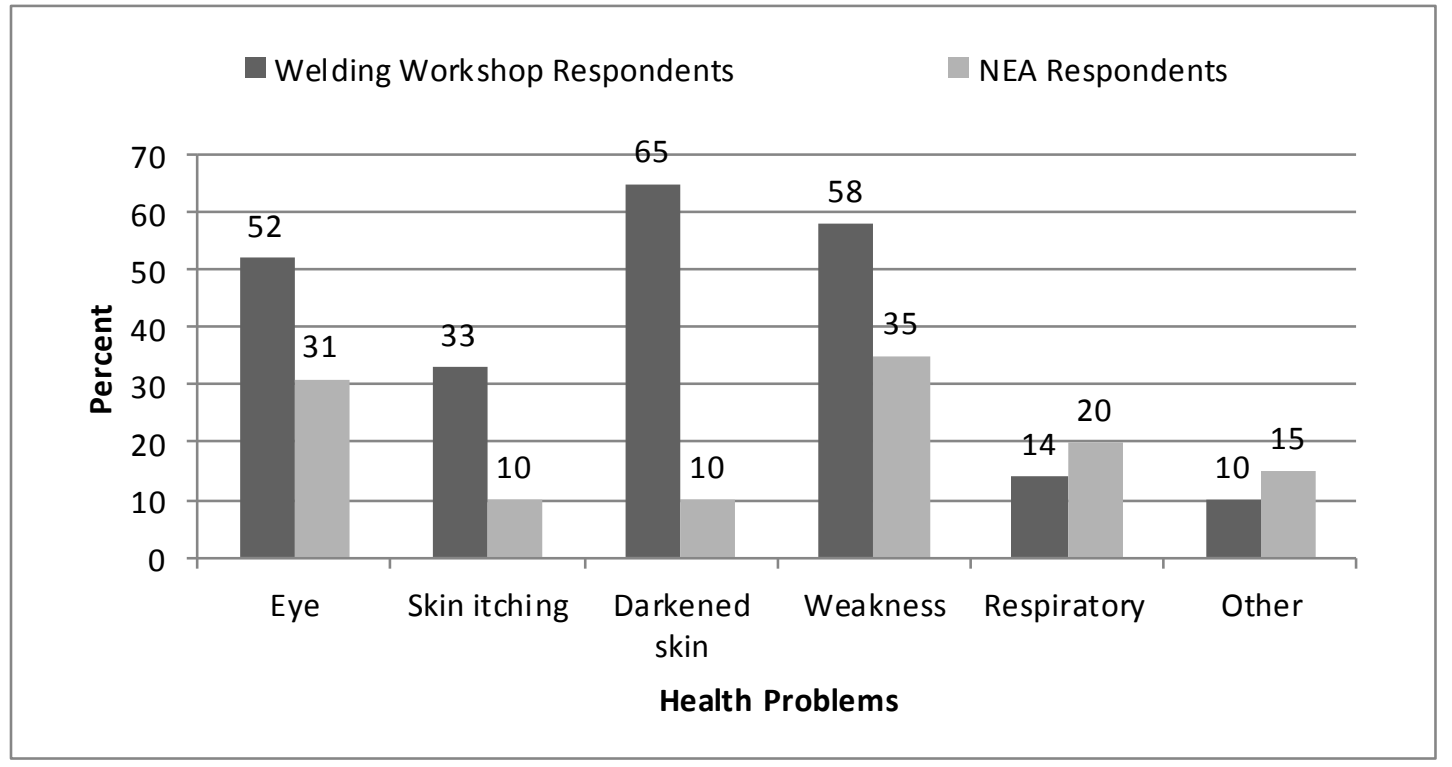

Figure 2: Health problems among the respondents

Most of the NEA workers had been in this service for the long period of time, however higher degree of health impacts was noticed among Welding Workshops Workers. This might be possibly due to poor awareness among respondents from Welding Workshop Workers. This condition was further worsened by the obstacles in managing workplace exposure due to poor or non-existent training, lack of safety equipment, substandard working conditions and inadequacies in monitoring of the ambient environment and inconsistencies in medical 
monitoring, diagnosis, reporting and treatment. This indicates that both NEA and welding workshop should put emphasis to increase the awareness level about the impacts of PCBs and contaminated transformer oil to improve the workplace conditions and to reduce the exposure of workers to the PCBs.

\section{Environmental Impacts and Awareness Conditions}

It was difficult to establish cause and effect relationships for environmental impact of PCBs and incident impact. As PCBs are no longer manufactured or widely used today, there are relatively few ways that PCBs is exposed to the environment (Stockholm Convention, 2004). The most common exposure routes in our country is through PCBs contaminated transformer oil which is widely used in transformers and welding workshop even today (Devkota, 2005).

There was very poor knowledge about impacts of PCBs contaminated transformer oil on environment among respondents. The condition was worse than reported by MOEST in 2007 (59\% of NEA employees and $14.3 \%$ of private workshops were aware of impacts of PCBs on the environment). The condition was better among NEA employees than among welding workshop workers, but yet not satisfactory. Among the respondents who had knowledge about impact of transformer oil on environment, very few had knowledge that PCBs could contaminate the whole environment through driving forces like wind, water, gravity and food chain and show multiple impacts.

Table 3: Summary of environmental impacts

\begin{tabular}{|l|l|l|l|l|}
\hline S.N. & $\begin{array}{l}\text { Environmental } \\
\text { Components }\end{array}$ & Route of Exposure & $\begin{array}{l}\text { Contamination } \\
\text { Conditions }\end{array}$ & Remarks \\
\hline 1 & Soil & $\begin{array}{l}\text { Transformers failure, } \\
\text { leaking, mishandling of } \\
\text { transformers and other } \\
\text { transformer oil containing } \\
\text { equipment }\end{array}$ & $\begin{array}{l}\text { 209.52 } \mathrm{m}^{2} \\
{[\text { Leaking }} \\
\text { transformers }], 80 \\
\mathrm{~m}^{2}[\mathrm{NEA} \\
\text { Lainchaur } \\
\text { Workshop }]\end{array}$ & $\begin{array}{l}\text { Soil } \\
\text { examination } \\
\text { for PCBs } \\
\text { contamination }\end{array}$ \\
\hline 2 & Ground water & Infiltration & ND & $\begin{array}{l}\text { Examination } \\
\text { around wells } \\
\text { near } \\
\text { workshops }\end{array}$ \\
\hline 3 & Surface water & $\begin{array}{l}\text { Runoff from PCBs } \\
\text { contaminated surface }\end{array}$ & $\begin{array}{l}\text { Examination } \\
\text { during first } \\
\text { rain }\end{array}$ \\
\hline 4 & Air & Similar to soil exposure & ND & Oil should be \\
\hline
\end{tabular}




\begin{tabular}{|l|l|l|l|l|}
\hline & & & & $\begin{array}{l}\text { stored in close } \\
\text { system }\end{array}$ \\
\hline 5 & Concrete & Mishandling at workshops & $\begin{array}{l}40 \mathrm{~m}^{2} \text { at } \\
\text { Lainchaur } \\
\text { Workshop }\end{array}$ & $\begin{array}{l}\text { Epoxy sealants } \\
\text { coating }\end{array}$ \\
\hline 6 & Wood & $\begin{array}{l}\text { Used as floor for storing } \\
\text { container, fabricating } \\
\text { materials }\end{array}$ & ND & $\begin{array}{l}\text { Examination } \\
\text { for PCBs } \\
\text { contamination }\end{array}$ \\
\hline 7 & Debris & Accidental contamination & ND & Safe disposal \\
\hline 8 & Equipment & $\begin{array}{l}\text { Transfer and transport of } \\
\text { PCBs contaminated oil }\end{array}$ & ND & $\begin{array}{l}\text { Examination } \\
\text { for PCBs } \\
\text { contamination }\end{array}$ \\
\hline
\end{tabular}

Immediate action is required to increase the knowledge about impact of PCBs contaminated transformer oil on health, and to increase the awareness about the use of PPE during working periods. And for sustainable solution, working conditions should be managed properly in order to reduce workplace exposure through training, safety equipment should be used properly, monitoring of PCBs in ambient environment and medical monitoring, diagnosis, reporting and treatment should be done regularly (Stockholm Convention, 2004).

According to UNEP Chemicals (1999) destruction of PCBs molecules present in the transformer oil can be done through physical, microbial and chemical method. In physical method PCBs contaminated transformer oil can me decontaminated either through incineration (in which PCBs contaminated oil is burnt at temperature of $1200^{\circ} \mathrm{C}$ for at least 2 seconds) or irradiation (in which PCBs contaminated transformer oil is subjected to gamma rays irradiation to convert into inorganic chloride) or pyrolysis (in which long-chain molecule of PCBs present in transformer oil are broken with extreme temperature provided by an electric arc in an inert environment). In microbial method, some micro-organisms are able to decompose PCBs; they work in one of two ways: either they use the PCB as a carbon source or destruction takes place through reductive dechlorination, with the replacement of chlorine with hydrogen on the biphenyl skeleton. In chemical method, there are many methods available to destroy PCBs, one of very common method is nucleophilic aromatic substitution, which is done by substituting chlorine of PCBs by polyethylene glycols to produce aryl polyglycols, which are insoluble in the oil and precipitate out. 


\section{Conclusion}

No PCBs contamination was found in power transformers in the Kathmandu valley; however contamination was found in distribution transformers. According to the guidelines prepared by Stockholm Convention, 7 among 17 decommissioned transformers at NEA Lainchaur workshop, 5 among 30 transformers under maintenance at same workshop and 172 among 1604 operational distribution transformers at different distribution centers of the Kathmandu valley were contaminated with PCBs (PCBs level greater than or equal to $50 \mathrm{ppm}$ ). The total quantity of $67566.3 \mathrm{Kg}$ PCBs contaminated transformer oil was found in the Kathmandu valley.

Around 209.52 square meter surface was found contaminated through leaking online (pole) transformers in different parts of the Kathmandu valley.

The level of knowledge about impact of PCBs contaminated transformer oil on health was very low among workers who, regularly come in contact with transformer oil in the Kathmandu valley. The level of knowledge was better among NEA employees (8\%) than among welding workshop workers (2\%), but not satisfactory.

It was very difficult to establish causality of illness or disease that was directly attributable to exposure to PCBs. As noted above it was found that the level of knowledge and awareness on health and environment about PCBs contaminated transformer oil on health and environment was very low among workers who, regularly come in contact with transformer oil.

\section{Acknowledgment}

The authors like to thank all the members of the College of Applied Sciences-Nepal for their support, Ministry of Science, Technology and Environment (MOSTE) for their laboratory support, Nepal Electricity Authority (NEA) for the support during field works in carrying out the research work. Special thanks goes to Ruska Kattel Kunwar and Annu Rajbhandari for their valuable suggestions and inspiration to carry out the work.

\section{References}

Basel Convention, 1989. Convention on the control of transboundary movement of hazardous waste and their disposal. United Nations, Treaty Series, 1673, p. 57. 
Devkota, B., 2005. Inventory of polychlorinated biphenyls (PCBs) in Nepal. Ministry of Environment Science and Technology, Nepal.

Dexsil Corporation, 2006. L2000DX User’s Manual. Generators Journal, 33, 557-563.

MOEnv., 2006. Inventory of polychlorinated biphenyls (PCBs) and inventory of persistent organic pollutants (POPs) in Nepal. MOEST and UNIDO, Nepal.

MOEST, 2007. National Implementation Plan for Stockholm Convention on persistant organic pollutants (POPs), Ministry of Environment, Nepal.

Nepal Electricity Authority, 2011. NEA Annual Report, Nepal.

Rotterdam Convention , 2004. Convention on the prior informed consent procedures for certain hazardous chemicals and pesticides in international trade. United Nations, Treaty Series, 2244, p. 337.

Safe, S. and Hutzinger, O., 1984. Polychlorinated biphenyls (PCBs) and polybrominated biphenyls (PBBs): biochemistry, toxicology, and mechanism of action. Critical Review Toxicology 13(4): 319-395.

Safe, S., S. Bandiera, T. Sawyer, L. Robertson, L. Safe, A. Parkinson, P. E. Thomas, D. E. Ryan, L. M. Reik and W. Levin, 1985. PCBs: structure-function relationships and mechanism of action. Environment Health Prospect, 134(3), 403-416.

Stockholm Convention, 2004. Convention on persistent organic pollutant. United Nations, Treaty Series, 2256, p.119.

UNEP, 1997. Guidelines for the identification of PCBs and Materials containing PCBs. United Nations, Guideline, 1673, p. 142.

UNEP Chemicals, 1999. Guidelines for the Identification of PCBs and Materials Containing PCBs. United Nations, Guideline, 164, p. 37.

WHO, 2001. Fact sheet about worldwide human health impacts of PCBs. Journal of hazardous materials, $162,1514-1521$. 